Int. J. Morphol.,

29(4):1414-1421, 2011.

\title{
Reproductive Strategies of Brazilian Lizards of the Genus Tropidurus Rodrigues, 1987 (Squamata, Tropiduridae) in the Temporal and Spatial
}

\author{
Estrategias Reproductivas de las Lagartijas Brasileñas del Género \\ Tropidurus Rodrigues, 1987 (Squamata, Tropiduridae) en lo Temporal y Espacial
}

"Adelina Ferreira; "Virginia Ojeda Kihara \& ${ }^{* *}$ Mahmoud Mehanna

FERREIRA, A.; KIHARA, V. O. \& MEHANNA, M. Reproductive strategies of Brazilian lizards of the genus Tropidurus Rodrigues, 1987 (Squamata, Tropiduridae) in the temporal and spatial. Int. J. Morphol., 29(4):1414-1421, 2011.

SUMMARY: Reproductive strategy is the set of adaptations that promote the most efficient way that the species will survive under the particular conditions of a determined environment. Understanding these adaptations is important and can help pinpoint populations indicator of environmental changes. Spermatogenesis is a measurable biological process of these adaptations in spatial and temporal scales. We analyzed the morphology of the testes and oviducts of the lizard species that comprise the genus Tropidurus, taking into account the geographical distribution and sympatric relations. For the analysis and the testes were removed from the middle part of the oviducts from Tropidurus etheridge, T. oreadicus, T. itambere, T. spinulosus and T. Guarani species, collected in different places in the Mato Grosso state, Brazil. The reproductive period is synchronous for males and females and occurs in September, October and November. Reproductive males were characterized. In the testes are seminiferous tubules with germ cells at different stages of spermatogenesis, with a high epithelium, at present light, free spermatozoa in the lumen and reduction of interstitial tissue. For females, the reproduction peak occurs when the oviduct epithelium is high with secretions and basal nucleus. These months are characterized in the sampled areas over a period of heavy rain and high temperatures. The decline of reproductive period was observed in both sexes, between April and August. Low reproduction in males is characterized by ample light, absence of sperm, only germ cells in the early stages of spermatogenesis are observed (a few spermatogonia and spermatocytes) and interstitial tissue wide. In females, the period of reproductive decline is marked by the absence of unicellular glands in the oviduct epithelium, with higher affinity with the dye. This period corresponds to low rainfall periods and lower temperatures. We propose an analysis of zoological samples; this is a proposal to facilitate the work of many researchers through access to the species, especially rare species.

KEY WORDS: Reproductive cycle; Lizards; Brazil.

\section{INTRODUCTION}

Reproductive strategy is the set of adaptations to promote the most efficient way for a population to survive under particular conditions of a certain environment (Tinkle et al., 1969; Ballinger, 1977).

The influence of environmental factors is evidenced by differences in reproductive strategies between populations of the same species inhabiting different places. In seasonal environments where climatic conditions are predictable, reproduction tends to occur during some periods (Vitt \& Colli, 1994). The reproductive strategies are reflected in the morphology of gonads, allowing the categorization of three types of reproductive cycles: continuous (Wilhoft, 1963; Inger \& Greenber, 1966), continuous with variation in reproductive behavior (Sexton et al., 1971; Ruibal et al., 1972), and discontinuous (Marion \& Sexton, 1971; Ferreira et al., 2002; Ferreira et al., 2009). Histologically, the continuous cycles are characterized by the presence of all classes of germ cells within seminiferous tubules at different stages of spermatogenesis throughout the year. The discontinuous cycle is characterized by extremes: at some times of the year are observed only primordial cells of spermatogenesis (spermatogonia) while during other periods are registered great proportions of mature cells of

\footnotetext{
* Universidade Federal de Mato Grosso (UFMT), Instituto de Biociências, Cuiabá, MT, Brasil.

** Universidade Estadual Paulista Julio de Mesquita Filho (UNESP), Pós-Graduação em Ciências Biológicas/Zoologia, Botucatu, SP, Brasil.
} 
spermatogenesis (sperm) filling all seminiferous tubule (Ferreira \& Dolder, 2002). What is not known is how the species that occur in open areas under different climatic conditions are influenced by the environment, and how the reproductive cycles are established, which factors can influence, and how long endure the phase of maximum gamete production.

The seasonality influencing on reproduction is common among temperate-zone lizards (Fitch, 1980) so that temperature and photoperiod are major determinants of reproductive activity and may determine a hibernation period for several species (Mayhew, 1964; Licht, 1973). In relation to the tropics, where temperature and photoperiod undergo lower variation, and where drought is comparable to the prolonged cold of temperate zones (Pianka, 1970), the precipitation is apparently the main factor and which most influences the reproductive cycles of lizards (Sexton et al., 1971; Ruibal et al., 1972; Ferreira et al., 2002; Ferreira et al., 2009). The importance of rainfall as a factor regulating the reproductive cycle is expressed both by the higher humidity, essential to prevent desiccation of the eggs, and by the greater availability of food resources (Vallejo \& Vallejo, 1981). Vitt \& Colli proposed to relate the foraging tactics with resource abundance and habitat features; in this way secondary forager lizards, due to its smaller displacement in the habitat, would be more prone to seasonal variations of resources and would tend to be seasonal in reproduction; on the other hand, active foragers, because they move into larger areas, could find productive spots in the habitat and would be less subject to restrictive effects of seasonality in environmental resources. However, there is no ratification of these relationships with the reproductive physiology, and the production and maturation of gametes in tropical lizards.

These differences in reproductive strategies are important considering that there are evolutionary historical mechanisms that operate on the morphological differentiation, physiology, and consequently the livelihood of lizards. Knowing this morphological differentiation involves understanding the current patterns of behavior, anatomy, physiology and geographical distribution of species.

Data were observed as regard the histology of the reproductive aspects for the family Tropiduridae ie, Tropidurus albermalensis (Stebbins et al., 1967) and Liolaemus austromendocinus and Prymaturus flagellifer (Furieri, 1974), T. hispidus (Prieto et al., 1976), T. delanonis (Werner, 1978), T. quadrivittatus and T. theresioides (Goldberg \& Rodriguez, 1986), T. torquatus (Cruz-Landim \& Cruz-Höfling, 1977; Cruz-Höfling \& Cruz-Landim 1978;
Vieira et al., 2001) and T. itambere (Van Sluys, 1993; Ferreira \& Dolder, 2003a, 2003b; Ferreira et al., 2006; Ferreira \& Dolder, 2007) and the family Iguanidae (ie. Saita et al. 1988; Ferreira et al., 2002), details of gametogenesis until fertilization of lizards under different climatic and seasonal conditions are scarcely known. The knowledge of reproductive patterns in different environmental conditions lead us to the evaluation of a measurable physiological response as indicator of environmental quality, and provided information to suggest more appropriate methods of management and conservation of biodiversity (Ferreira $e t$ al., 2002, 2009).

Through the morphological analysis of gonads, the conducting channels of gametes of the species compounding the genus Tropidurus, considering the wide geographical distribution and sympatric relationships, the present study aims to corroborate for the understanding of variations in reproductive strategies of these lizards.

\section{MATERIAL AND METHOD}

For the histological analysis, we removed male gonads, and the middle part of the oviduct of female species of lizards Tropidurus etheridgei (Cei, 1982); T. oreadicus (Rodrigues); T. itambere (Rodrigues); T. spinulosus (Cope, 1862); T. guarani (Cope, 1862). These samples were taken from specimens belonging to the sector of Herpetology Zoological Collection of the Federal University of Mato Grosso, Brazil (Table I).

For the analysis of reproductive cycles a total of 64 individuals were sampled, 35 males and 28 females, all from scientific collections. We recorded the following morphometric data: snout-vent length (SVL, to the nearest $1 \mathrm{~mm})$. Samples were collected in different months throughout the year between the years 1981 to 2007 and thus we analyzed the temporal scale. The localities are distributed in the States of Mato Grosso, Mato Grosso do Sul and Pará, Brazil, and in this way we analyzed the spatial scale (Table I, Fig. 1).

Were carried preparation techniques for conventional light microscopy, in order to diagnose the stages of gonad differentiation and characterization of conducting channels of gametes as well as for demonstration of increased glandular secretion. The samples were dehydrated in alcohol at increasing concentrations from 70 to $100 \%$ with halves of 30 minutes each, infiltrated for 24 hours and embedded in plastic resin (glycol methacrylate - HistoresinÒ) according to the protocol suggested by the manufacturer. The sections 
FERREIRA, A.; KIHARA, V. O. \& MEHANNA, M. Reproductive strategies of Brazilian lizards of the genus Tropidurus Rodrigues, 1987 (Squamata, Tropiduridae) in the temporal and spatial. Int. J. Morphol., 29(4):1414-1421, 2011.

Table I. Local and period of collection.

\begin{tabular}{|c|c|c|c|c|}
\hline Species & Local collection & Month & Year & Voucher specimens \\
\hline T. etheridgei & Corumbá - Mato Grosso State & $\begin{array}{l}\text { May, August, September } \\
\text { and October }\end{array}$ & $\begin{array}{l}2001,2002 \text { and } \\
2003\end{array}$ & $\begin{array}{l}1303,1345,1486,1494, \\
1496,6203,6204,6205, \\
6206,6209,6210,6207, \\
6208,6211,6212,6216, \\
6689,6690,6691,6692, \\
6693,6713\end{array}$ \\
\hline \multirow[t]{2}{*}{ T. guarani } & $\begin{array}{l}\text { Santo Antônio do Leverger, } \\
\text { Barão de Melgaço, Cáceres, } \\
\text { Chapada dos Guimarães, Porto }\end{array}$ & $\begin{array}{l}\text { January, March, April, } \\
\text { May, August, } \\
\text { September, October, }\end{array}$ & $\begin{array}{l}\text { 1981, 1982, } \\
1984,1992 \\
1993,1994\end{array}$ & $\begin{array}{l}56,99,193,406,407,408, \\
409,410,411,412,413, \\
414,1765,2649,2650,2651,\end{array}$ \\
\hline & $\begin{array}{l}\text { Esperidião and Barra do Bugres } \\
\text { - Mato Grosso State }\end{array}$ & $\begin{array}{l}\text { November and } \\
\text { December }\end{array}$ & $\begin{array}{l}1999,2000, \\
2001 \text { and } 2005\end{array}$ & $\begin{array}{l}2652,2761,2762,2763 \\
2764,2765,2767,2768, \\
5091,6888\end{array}$ \\
\hline$T$. oreadicus & $\begin{array}{l}\text { Chapada dos Guimarães, } \\
\text { Cuiabá, Alto Paraguai and } \\
\text { Carajás - Mato Grosso State }\end{array}$ & $\begin{array}{l}\text { March, April, May, } \\
\text { June, July, September, } \\
\text { October and December }\end{array}$ & $\begin{array}{l}1998,1999 \\
2000,2001 \\
2002,2003 \text { and } \\
2005\end{array}$ & $\begin{array}{l}308,450,452,453,820 \\
1044,2622,4334,6890 \\
6891\end{array}$ \\
\hline T. itambere & $\begin{array}{l}\text { Nova Bandeiran tes and Juara - } \\
\text { Mato Grosso State }\end{array}$ & August & 2007 & $5968,5969,5981$ \\
\hline T. spinulosus & $\begin{array}{l}\text { Itiquira and Chapada dos } \\
\text { Guimarães - Mato Grosso State }\end{array}$ & $\begin{array}{l}\text { December to March and } \\
\text { September }\end{array}$ & 1994 and 2001 & 2648,2766 \\
\hline
\end{tabular}

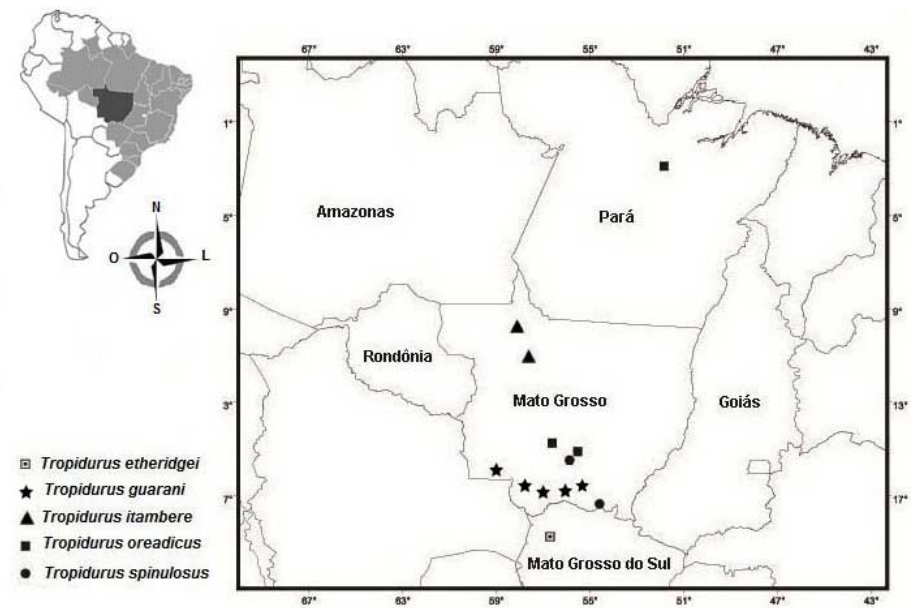

Fig. 1. Location of collection areas.

were stained by toluidine blue at $1 \%$, and and whenever necessary to evidence the glandular features were stained by toluidine blue at $1 \%$.

For the testes were considered the height of the germinal epithelium, the presence or absence of lumen, the presence or absence of free spermatozoa in the lumen, variations in proportions of interstitial tissue. For the conducting channels of gametes in the female we considered the changes in the appearance of the epithelium, and presence or absence of glandular secretions in the wall.
Changes in spermatogenesis and changes in the oviducts of females were related to climatic variations of the sampled areas. We considered the average values in the sampled months and years of rainfall and air temperature. Only the punctual data of sampled periods are presented, during some months these collections were not undertaken, and therefore not presented in climatic data (Fig. 2, Table II). These data were obtained from the INPE (National Institute for Space Research).

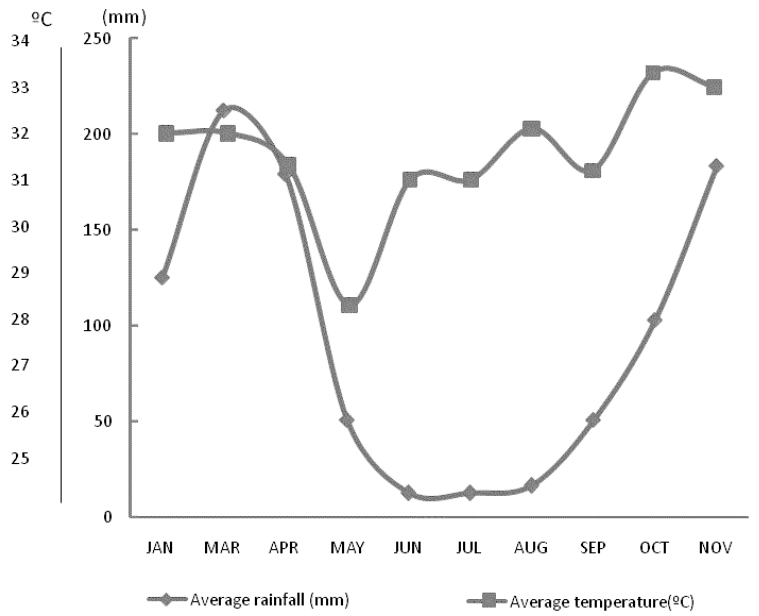

Fig. 2. Average variations in temperature and rainfall during sampled months in the studied areas. 
Table II. Monthly average values of temperature and rainfall in the studied areas.

\begin{tabular}{lcc}
\hline & Temperature $\left({ }^{\mathbf{O}} \mathbf{C}\right)$ & Rainfall $(\mathbf{m m})$ \\
\hline January & 32 & 125 \\
March & 32 & 212.5 \\
April & 31.3 & 179.16 \\
May & 28.3 & 50.5 \\
June & 31 & 12.5 \\
July & 31 & 12.5 \\
August & 32.1 & 16.5 \\
September & 31.2 & 50.5 \\
October & 33.3 & 103 \\
November & $33^{\circ}$ & 183.4 \\
\hline
\end{tabular}

\section{RESULTS}

The average length of males was $7.64 \mathrm{~cm}$ (SVL). The females showed the average length of $9.04 \mathrm{~cm}$ (SVL).

According to the characters for the reproductive states observed at light microscopy, were determined the periods of maximum or peak spermatogenesis in males, and testicular recrudescence or reproductive arrest in males. For females the peak reproductive period was determined as the period with maximum glandular production in the ducts or oviducts conducting the gametes (Figs. 3 and 4).
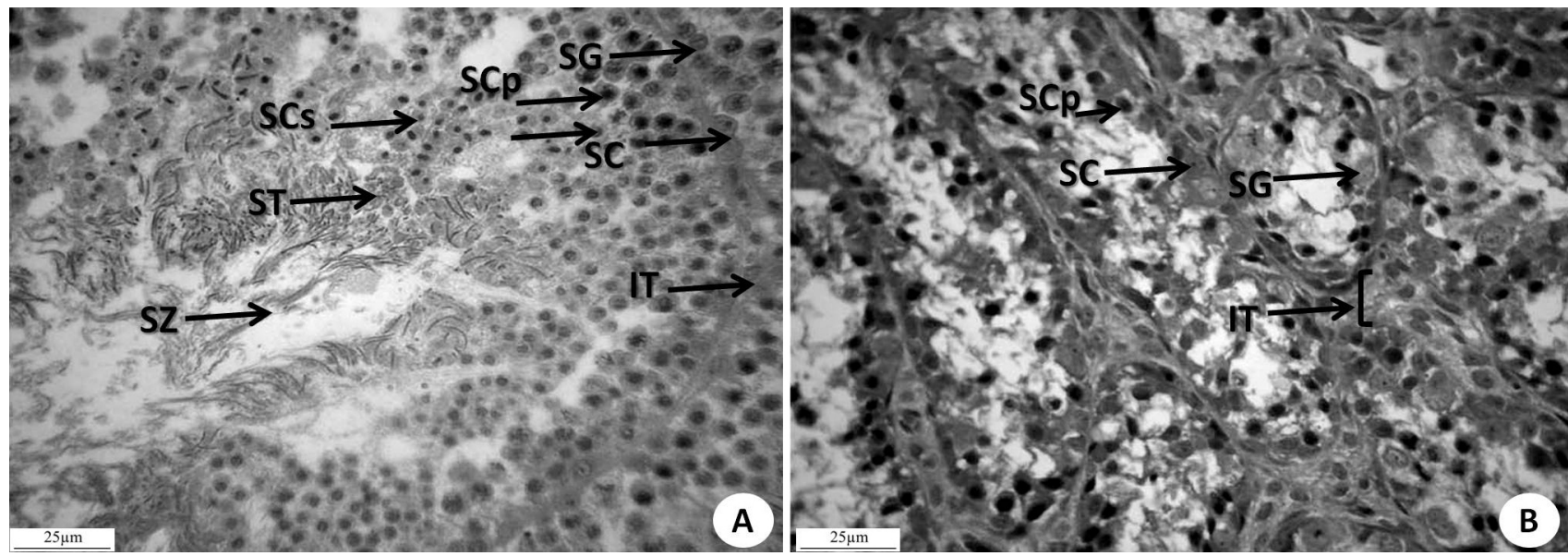

Fig. 3. A. Seminiferous tubule of Tropidurus etheridgei in the period of maximum spermatogenesis. B. Seminiferous tubule of T. etheridgei during the low reproductive period. 600x. IT: interstitial tissue, SC: Sertoli cell, SG: spermatogonia, SCp: primary spermatocyte, SCs: secondary spermatocyte, ST: spermatid, SZ: spermatozoa.
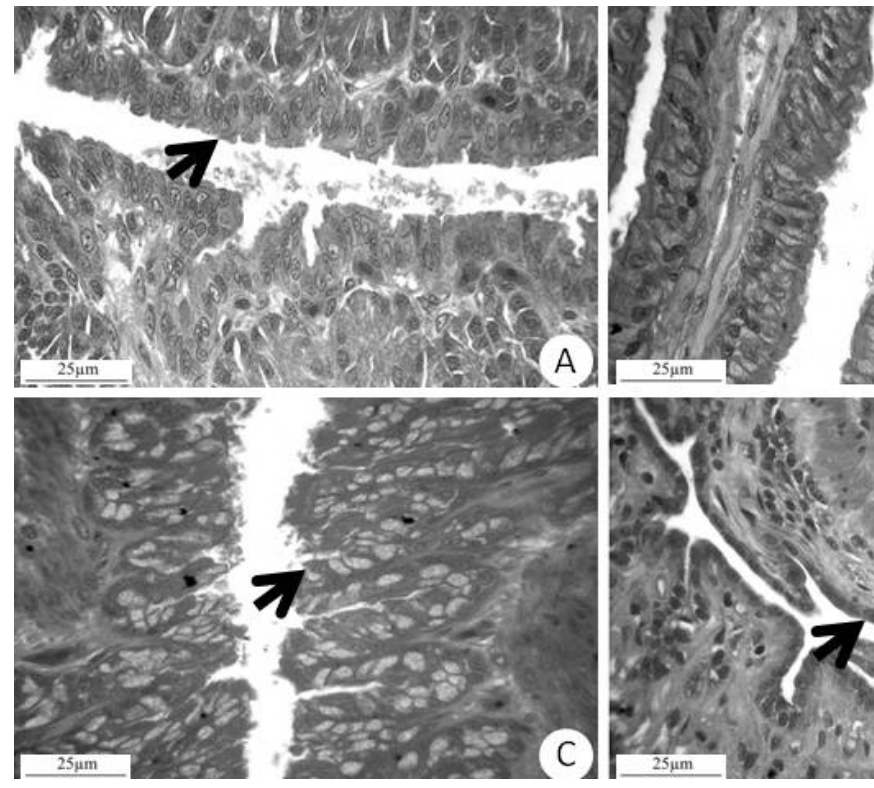

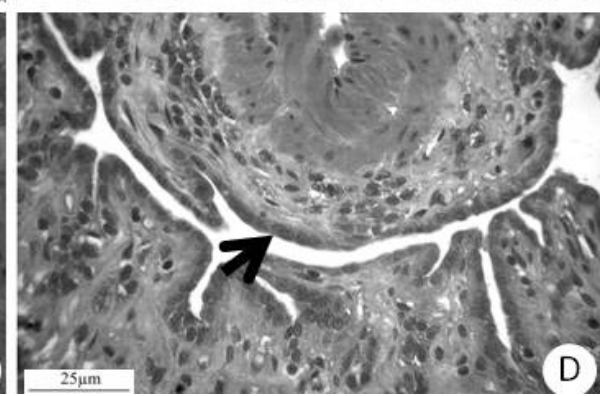

Fig. 4. A - D. Changes during the reproductive cycle in the morphology of the conducting channel of gametes (oviduct). A. Tropidurus etheridgei in August, beginning of the height increase of the lining epithelium that is not yet secreting (arrow). B. T. etheridgei in September, beginning of secretion production in lining epithelium. C. T.guarani in November, at the peak of production of glandular secretions. D. T. oreadicus in May, with very thin lining epithelium without secretory function. In all figures, the arrows indicate the lining epithelium. All the analyzed samples were taken from the median portion. 
There is a pattern within the genus in which the cycles of males and females coincide in their reproductive states of the lizards examined here. The reproductive peak for males is characterized by seminiferous tubules filled with germ cells at different stages of spermatogenesis, with very high epithelium, lumen is present but reduced, numerous free spermatozoa in the lumen, and reduced interstitial tissue (Fig. 3). The low or arrest of reproduction is characterized by thin germinal epithelium, with wide lumen, absence of sperm cells, with germ cells only at early stages of spermatogenesis (spermatogonia and few spermatocytes), and wider interstitial tissue (Fig. 3b).

For females the reproductive peak occurs when the conducting channels of gametes (oviduct) present an epithelium filled with unicellular glands, very similar to goblet cells, with clear secretion and basal nucleus (Figs. 4a, 4b, 4c). The low reproductive period is marked by the absence of these unicellular glands in the epithelium of conducting channels of gametes, or that they are inactive as glands and assume the role of lining cells. In this low reproductive period the epithelium of the conducting channels of gametes becomes thinner and with higher affinity with the dye used (Fig. 4d).

This peak reproductive period for both males and females usually occurs during September, October and November. These months are characterized in the sampled areas by a period of intense rainfall and temperatures a little higher (Fig. 2). The low reproductive period was observed in both sexes from April to August. This corresponds to periods of reduced rainfall and temperatures a little lower (Fig. 2).

For the reproductive cycle, we rated the following characters: in males (1) height of the germinal epithelium in the seminiferous tubules, (2) presence or absence of lumen in the seminiferous tubules, (3) presence or absence of free spermatozoa in the lumen of the seminiferous tubules, and (4) changes in the proportion of interstitial tissue. For females: (5) height of the epithelium in the oviduct, (6) presence or absence of active glands in the epithelium of the oviduct; and for both sexes: (7) relationships of the maximum sperm production with climatic variations, especially rainfall, the most important factor for lizards, and (8) relationships of maximum glandular activity in oviducts of females with climatic variations, mainly rainfall.

\section{DISCUSSION}

Species of Tropidurus are common in open and forested areas of Brazil (Rodrigues), where the populations are usually found in abundance. Lizards of this genus are diurnal, omnivorous, sit-and-wait forager (Van Sluys), which usually reproduce seasonally. A wide range of reproductive strategies are found between the Squamata (Tinkle et al.). The occurrence of different reproductive tactics among sympatric species under the same environmental conditions suggests the prevalence of phylogenetic effects (Vitt \& Goldberg, 1983). The influence of environmental factors becomes evident when there are different reproductive tactics among populations of the same species inhabiting different regions (Vitt \& Colli). Tropical lizards have many types of reproductive cycles (Vitt \& Goldberg), but in some species, it is not possible to identify a single factor that drives these cycles (eg, Vitt \& Goldberg). However, some authors assure that the reproductive activity of tropical species inhabiting seasonal environments is under the effects of rainfall (Colli, 1991; Van Sluys et al., 1987). The few studies that include a large number of locations hinder a better understanding of the association between reproductive activity and environmental factors on the lizards of the genus Tropidurus (Wiederhecker et al., 2002). However, important information about the reproductive activity of Neotropical lizards has arisen from studies of members from the family Tropiduridae (sensu Frost et al., 2001). In general, tropidurid lizards present their reproductive cycle in seasonal habitats; and studies on the ecology and reproductive cycles of some species of the genus Tropidurus has currently been studied, including T. etheridgei (Cruz, 1997), T. spinulosus (Cruz et al., 1997), T. semitaeniatus (Vitt \& Goldberg; Ribeiro et al., 2010); T. montanus (Van Sluys et al.); T. hispidus (Vitt \& Goldberg; Vitt et al., 1996), T. oreadicus (Rocha \& Bergallo, 1990), T. itambere (Van Sluys; Ferreira et al., 2009) and T. torquatus (Bergallo \& Rocha, 1993, 1994; Giaretta, 1996; Vieira et al.; Wiederhecker et al.) (see Table III).

When considering the climatic variables most relevant to influence the reproduction of lizards, the most important are the temperature and rainfall. Furthermore, this latter variable is the climatic factor that presents higher variation in the sampled areas. In Mato Grosso State, where the higher areas are formed by plateaus, the altitude associated to the winds is the geographical factor that most influences the variations in temperature and rainfall. Thereby, the cities of Cuiabá (180m altitude) and Chapada dos Guimarães (800m altitude), although located in similar latitudes, have different thermal conditions and rainfall. In Cuiabá, temperature is higher and total rainfall is lower than those found in Chapada dos Guimarães. The climate of Mato Grosso State is classified as typical of equatorial and tropical regions, where high temperatures prevail throughout the year, with high daily thermal amplitudes and small variations in average annual temperature (Fig. 2). These characteristics, combined with a dry period (autumn-winter) and a wet season (spring-summer) define the climate of this Brazilian State (Maitelli, 2005). 
Table III. Summary of the reproductive cycle of studied species in Brazil. The localities are presented with abbreviated States (MS- Mato Grosso do Sul State, MT- Mato Grosso State, PA- Pará State, PE- Pernambuco State, MG- Minas Gerais State, RR- Roraima State, SPSão Paulo State, FD- Federal District). We included two species studied in Argentina. The reproductive period is represented by the months in which the animals are observed with ecological characteristics of reproductive capacity and or with complete spermatogenesis observed histologically.

\begin{tabular}{|c|c|c|c|c|}
\hline Species & Reproductive period & Local & Biome & Author \\
\hline T. etheridgei & September to February & Salta - Argentine & 'Chaco' & Cruz, 1997 \\
\hline T. spinulosus & November to January & Salta - Argentine & 'Chaco' & Cruz et al., 1997 \\
\hline T. semitaeniatus & July to January & Exu (PE) & 'Caatinga' & Vitt \& Goldberg, 1983 \\
\hline T. montanus & August to January & Serra do Cipó (MG) & Atlantic forest & V an Sluys et al., 2002 \\
\hline T. hispidus & November to March & Northeast & 'Caatinga' & Vitt \& Goldberg, 1983 \\
\hline T. hispidus & June to July & Caracaraí (RR) & Amazon & Vitt et al., 1996 \\
\hline T. oreadicus & & & Amazon & Rocha \& Bergallo, 1990 \\
\hline T. itambere & January to April & Valinhos (SP) & Atlantic forest & Van Sluys, 1993 \\
\hline T. itambere & June to September & Valinhos (SP) & Atlantic forest & Ferreira et al., 2009 \\
\hline T. torquatus & August to January & Brasilia (FD) & 'Cerrado' & Vieira et al., 2001 \\
\hline T. torquatus & August to January & Brasilia (FD) & 'Cerrado' & Wiederhecker et al., 2002 \\
\hline T. semitaeniatus & November to March & Serra Negra do Norte (RN) & 'Caatinga' & Ribeiro et al., 2010 \\
\hline T. etheridgei & September, October & Corumbá (MS) & Pantanal & Present study \\
\hline T. guarani & November, December & $\begin{array}{l}\text { Barão de Melgaço (MT), Chapada } \\
\text { dos Guimarães (MT), Poconé (MT) }\end{array}$ & $\begin{array}{l}\text { Pantanal and } \\
\text { 'Cerrado' }\end{array}$ & Present study \\
\hline T. oreadicus & September to November & $\begin{array}{c}\text { Chapada dos Guimarães (MT), } \\
\text { Carajás (PA) }\end{array}$ & $\begin{array}{l}\text { ‘Cerrado', } \\
\text { Amazon }\end{array}$ & Present study \\
\hline T. spinulosus & September to November & $\begin{array}{l}\text { Itiquira(MT), Chapada dos } \\
\text { Guimarães(MT) }\end{array}$ & ‘Cerrado’ & Present study \\
\hline T. itambere & September, October & $\begin{array}{l}\text { Juara(MT), Nova } \\
\text { Bandeirantes(MT) }\end{array}$ & Amazon & Present study \\
\hline
\end{tabular}

The data herein presented show that the cycles of spermatogenesis and of preparation of the female body to conduct the gametes are similar and respond positively to climate variations. The air temperature suffered a few variations throughout the year. The climatic factor that goes through major variations is the rainfall abundance. Moreover, apparently rainfall is the factor that determines the ideal time for reproduction of these lizards. The cycles do not vary when observed in long periods. Therefore, variations in temporal scale are not perceived. Despite the State of Mato Grosso presents three well-defined biomes, totally and mutually different, these environmental changes seem not to affect the reproductive strategies adopted by the genus, which did not present changes in spatial scale. Through the observations in the literature and exposed in Table III, the variations in spatial scale does not occur to the genus in Brazil as a whole. This demonstrates that the reproductive strategies adopted by genus Tropidurus are highly conserved in spatial and temporal scales.

ACKNOWLEDGEMENTS. This work is supported by grants from Fundação de Amparo à Pesquisa do Estado de Mato Grosso - FAPEMAT (process n ${ }^{\circ} 737194 / 2008$ ).

FERREIRA, A.; KIHARA, V. O. \& MEHANNA, M. Estrategias reproductivas de las lagartijas Brasileñas del género Tropidurus Rodrigues, 1987 (Squamata, Tropiduridae) en lo temporal y espacial. Int. J. Morphol., 29(4):1414-1421, 2011.

RESUMEN: Estrategia reproductiva es el conjunto de adaptaciones que promueven la manera más eficiente para una población a sobrevivir en las condiciones específicas de un entorno particular. Comprender esta adaptación es importante y puede identificarse en algunas poblaciones como indicador de cambios ambientales. La espermatogénesis puede ser un proceso biológico medible de estas adaptaciones en escalas espaciales y temporales. Se analizó la morfología de los testículos y oviductos de las especies de lagartijas que componen el género Tropidurus, teniendo en cuenta la amplia distribución geográfica y las relaciones simpátricas. Para el análisis hemos eliminado los testículos de los machos y la parte media de los oviductos de hembras de las especiesTropidurus Etheridge, T. oreadicus, T. itambere, T. spinulosus y T. Guarani recolectadas en diferentes lugares en el estado de Mato Grosso, Brasil. El período reproductivo es sincró- 
nico para machos y hembras, y se produce durante septiembre, octubre y noviembre. Se caracterizaron como machos reproductores por testículos con túbulos seminíferos con células germinales en distintas etapas de la espermatogénesis, un epitelio muy alto, un lumen reducido, numerosos espermatozoides libres en el lumen y tejido intersticial redicudo. En hembras el pico reproductivo se produce cuando los canales de conducción de gametos poseen un epitelio alto, secretor y con núcleos basales. Estos meses son caracterizados en las zonas muestreadas por fuertes lluvias y altas temperaturas. La disminución del período reproductivo se observó en ambos sexos, entre abril y agosto. La baja reproducción en machos se caracteriza por un lumen ancho, ausencia de espermatozoides, presencia de células germinales sólo en las primeras etapas de la espermatogénesis (espermatogonias y pocos espermatocitos) y tejido intersticial amplio. En las mujeres, el período de baja reproducción está marcado por la ausencia de glándulas unicelulares en el epitelio del oviducto, con mayor afinidad a la tinción. Este período corresponde al de baja precipitaciones y temperaturas más bajas. Proponemos un análisis de muestras de las colecciones zoológicas ya que esta es una propuesta para facilitar el trabajo de muchos investigadores a través del acceso a las especies, especialmente especies raras.

Brasil.

PALABRAS CLAVE: Ciclo reproductivo; Lagartos;

\section{REFERENCES}

Ballinger, R. E. Reproductive Strategies: Food Availability as a Source of Proximal Variation in a Lizard. Ecology, 58:628-35, 1977.

Bergallo, H. G. \& Rocha, C. F. D. Activity patterns and body temperatures of two sympatric lizards (Tropidurus torquatus and Cnemidophorus ocellifer) with different foraging tactics in southeastern Brazil. Amphibia-Reptilia, 14(3):312-5, 1993.

Bergallo, H. G. \& Rocha, C. F. D. Spatial and trophic niche differentiation in two sympatric lizards (Tropidurus torquatus and Cnemidophorus ocellifer) with different foraging tactics. Australian J. Ecol., 19(1):72-5, 1994.

Colli, G. R. Reproductive ecology of Ameiva ameiva (Sauria: Teiidae) in the cerrado of central Brazil. Copeia, 4:1002-12, 1991.

Cruz, F. B.; Teisaire, E. \& Nieto, L. Reproductive Biology of the Lizard Tropidurus spinulosus in the Chaco of Salta, Argentina. Stud. Neotrop. Fauna Environ., 32(1):28-32, 1997.

Cruz, F. B. Reproductive activity in Tropidurus etheridgei in the semiarid Chaco of Salta, Argentina. J. Herpetol., 31(3):44450, 1997.

Cruz-Höfling, M. A. \& Cruz-Landim, C. The fine structure of nuclei during spermiogenesis in the lizard Tropidurus torquatus (Lacertilia). Cytologia, 43:61-8, 1978.
Cruz-Landim, C. \& Cruz-Höfling, M. A. Electron microscope study of lizard spermiogenesis in Tropidurus torquatus (Lacertilia). Caryologia, 30:151-62, 1977.

Ferreira, A. \& Dolder, H. Ultrastructural analysis spermiogenesis in Iguana iguana (Reptilia: Sauria: Iguanidae). Eur. J. Morphol., 40(2):89-99, 2002.

Ferreira, A.; Laura, I. \& Dolder, H. Reproductive cycle of male green iguanas, Iguana iguana (reptilla: sauria: iguanidae), in the Pantanal region of Brazil. Braz. J. Morphol. Sci., 19(1):238, 2002.

Ferreira, A. \& Dolder, H. Sperm ultrastructure and spermatogenesis in the lizard, Tropidurus itambere. Biocell, 27(3):353-62, $2003 a$.

Ferreira, A. \& Dolder, H. Cytochemical study of the spermiogenesis and mature spermatozoon of the lizard, Tropidurus itambere (Reptilia, Squamata). Acta Histochem., 105(4):339-52, 2003b.

Ferreira, A.; Mehanna, M. \& Dolder H. Ultrastructural immunocytochemical evidence for actin in the acrosomal complex during spermiogenesis of the lizard Tropidurusitambere (Rodrigues, 1987) (Reptilia: Tropiduridae). Caryologia, 59(3):213-9, 2006.

Ferreira, A. \& Dolder, H. Histology, histochemistry and ultrastructure of the oviducts and seminal receptacle of Tropidurus itambere (Rodrigues, 1987) (Reptilia, Tropiduridae). Braz. J. Morphol. Sci., 24(1):29-38, 2007.

Ferreira, A.; Silva, D. N.; Van Sluys, M. \& Dolder, H. Seasonal Changes in Testicular and Epididymal Histology of the Tropical Lizard, Tropidurus itambere (Rodrigues, 1987), during its Reproductive Cycle. Braz. J. Biol., 69(2):429-35, 2009.

Fitch, H. S. Reproductive strategies of reptiles. In: Muphy, J. B. \& Collins, J. J. (Eds.). Reproductive biology and diseases of captive reptiles. SSAR Contributions of Herpetology 1. New York, Society for the Study of Amphibians and Reptiles, 1980.

Frost, D. R.; Etheridge, R.; Janies, D. \& Titus, T. A. Total evidence, sequence alignment, evolution of polychrotid lizards and a reclassification of the Iguania (Squamata: Iguania). Am. Museum Novitates, 3343:1-38, 2001.

Furieri, P. Spermi e spermatogenesi in alcuni iguanidi argentini. Riv. Biol., 67:233-79, 1974.

Giaretta, A. A. Lacertilia: Tropidurus torquatus (NCN). Home range. Herpetol. Rev., 27:80-1, 1996.

Goldberg, S. R.; Rodriguez, E. Reproductive cycles of two iguanid lizards from northern Chile, Tropidurus quadrivittatus and $T$. theresioides. J. Arid. Environ., 10:147-51, 1986.

Inger, R. F. \& Greenber, B. Annual Reproductive Patterns of lizards from a Bornean rain forest. Ecology, 47(6):1007-10, 1966. 
Licht, P. Environmental influences on the testis cycles of the lizards Dipsosaurus dorsales and Xantusia vigilis. Comp. Biochem. Physiol. A Comp. Physiol., 45(1):7-20, 1973.

Maitelli, G. T. Interações atmosfera-superfície. In: Moreno, G. \& Higa, T. C. S. (Ed). Geografia de Mato Grosso: território, sociedade, ambiente. Cuiabá, Ed. Entrelinhas, 2005. pp.23849.

Marion, K. R.; Sexton, O. J. Reproductive cycle of lizard Sceloporus malachiticus in Costa Rica. Copeia, 3:517-20, 1971.

Mayhew, W. W. Photoperiodic responses in three species of the lizard genus Uma. Herpetologica, 20(2):95-113, 1964.

Pianka, E. R. Comparative autoecology of the lizard Cnemidophorus tigris in different parts of its geographic range. Ecology, 51:703-20, 1970.

Prieto, A. S.; Leon, J. R. \& Lara, O. Reproduction in the tropical lizard, Tropidurus hispidus (Sauria: Iguanidae). Herpetologica, 32:318-23, 1976.

Ribeiro, L. B.; Kolodiuk, M. F. \& Freire, E. M. X. Ventral Colored Patches in Tropidurus semitaeniatus (Squamata, Tropiduridae): Sexual Dimorphism and Association with Reproductive Cycle. J. Herpetol., 44:177-82, 2010.

Rocha, C. F. D. \& Bergallo, H. G. Thermal biology and flight distance of Tropidurus oreadicus (Sauria: Iguanidae) in an area of Amazonian Brazil. Ethol. Ecol. Evol., 2:263-8, 1990.

Rodrigues, M. T. Sistemática, ecologia e zoogeografia dos Tropidurus do grupo Torquatus ao Sul do Rio Amazonas (Sauria: Iguanidae). Arq. Zool. SP, 31:105-230, 1987.

Ruibal, R.; Philibosian, R. \& Adkins, J. L. Reproductive cycle and growth in the lizard Anolis acutus. Copeia, 3:509-18, 1972.

Saita, A.; Comazzi, M. \& Perrota, E. New data at the E. M. on the spermiogenesis of Iguana delicatissima (Laurent) involving comparative significance. Acta Embryol. Morphol. Exper., 9:105-14, 1988

Sexton, O. J.; Ortleb, E. P.; Hathaway, L. M.; Ballinger, R. E. \& Licht, P. Reproductive cycles of three species of anoline lizards from the Isthmus of Panama. Ecology, 52:201-15, 1971.

Stebbins, R. C.; Lowenstein, J. M. \& Cohen, N. W. A field study of the lava lizard (Tropidurus albemarlensis) in the Galapagos Islands. Ecology, 48:839-51, 1967.

Tinkle, D. W. The concept of reproductive effort and its relation to the evolution of life histories of lizards. Amer. Natur., 103:50116,1969

Vallejo, L. R. \& Vallejo, M. S. Contribuição ao estudo ecológico dos microartrópodos do "litter" na restinga de Maricá. RJ. Rev. Bras. Biol., 41:539-43, 1981.
Van Sluys, M.; Mendes, H. M. A.; Assis, V. B. \& Kiefer, M. C. Reproduction of Tropidurus montanus Rodrigues, 1987 (Tropiduridae), a lizard from a seasonal habitat of southeastern Brazil, and a comparison with other Tropidurus species. Herpetol. J., 12:89-97, 1987.

Van Sluys, M. The reproductive cycle of Tropidurus itambere (Sauria: Tropiduridae) in Southeastern Brazil. J. Herpetol., 27:28-32, 1993

Vieira, G. H. C.; Colli, G. R.; Báo, S. N. \& Wiederhecker, H. C. Spermiogenesis and testicular cycle of the lizard Tropidurus torquatus (Squamata, Tropiduridae) in the Cerrado of central Brazil. Amphibia-Reptilia, 22:217-33, 2001.

Vitt, L. J. \& Colli, G. R. Geographical ecology of a neotropical lizard: Ameiva ameiva (Teiidae) in Brazil. Can. J. Zool., 72:1986-2008, 1994.

Vitt, L. J. \& Goldberg, S. R. Reproductive ecology of two tropical iguanid lizards: Tropidurus torquatus and Platynotus semitaeniatus. Copeia, 1:131-41, 1983.

Vitt, L. J.; Zani, P. A. \& Caldwell, J. P. Behavioral ecology of Tropidurus hispidus on isolated rock outcrops in Amazonia. $J$. Trop. Ecol., 12:81-101, 1996.

Werner, D. I. On the biology of Tropidurus delanonis, Baur (Iguanidae). Z. Tierpsychol., 47:337-95, 1978.

Wiederhecker, H. C.; Pinto, A. C. S. \& Colli, G. R. Reproductive ecology of Tropidurus torquatus (Squamata: Tropiduridae) in the highly seasonal Cerrado biome of central Brazil. $J$. Herpetol., 36:82-91, 2002.

Wilhoft, D. C. Gonadal histology and seasonal changes in tropical Australian lizard, Leiolopisma rhomboidalis. J. Morphol., 113:185-204, 1963

Correspondence to:

Dra. Adelina Ferreira

Universidade Federal de Mato Grosso (UFMT)

Depto de Biologia e Zoologia, IB, UFMT

Av. Fernando Correia, s/n, cep 78060-900

Cuiabá, MT

BRASIL

Email: adelina@ufmt.br

Received: 26-05-2011

Accepted: 02-11-2011 